\title{
THE COMPOSITE LEADING INDICATOR FOR GERMAN BUSINESS CYCLE
}

\author{
- Tkacova Andrea, Gavurova Beata, Behun Marcel
}

\begin{abstract}
Monitoring and predicting economic cycles have returned to the awareness of economists with the impact of the economic crisis in 2007/2008. To determine the current and future state of the country's economic cycle, Composite Leading Indicators (CLI) can be used. Their structure is being dealt with by institutions at the national and international level (OECD, Eurostat). Correct predictions of public finance development and the entrepreneurship sphere are very important for competitiveness of the country. The aim of the paper is to propose a new Composite Leading Indicator (CLI) to monitor and predict the German economy. The analysis of 140 quantitative and qualitative indicators of industry, services, retail, construction, foreign trade, labor market, money aggregates, stock indices, confidence indicators, consumer expectations was performed for the needs of the indicator. As the reference series represents the German economic cycle, the GDP indicator is selected at constant prices for 2010. All selected quarterly time series are applied with seasonal index methods, the Hodrick-Prescott filter (HP filter) in the R program, cross-correlation with time shifts, methods selection and scoring, data standardization, identification of the same and different data and the subsequent construction of the CLI of the German economic cycle. The generated CLI can predict the German economy cycle two quarters ahead with a cross-correlation value of 0.867 . The forecasting capabilities of the assembled indicator were better than the prediction capabilities of OECD, Eurostat and IFO indicator.
\end{abstract}

Keywords: composite leading indicator, business cycle, gross domestic product, cyclical indicators, cross correlation JEL Classification: E32, E37

\section{INTRODUCTION}

The tracking of economic cycles using composite leading indicators has its foundations in the 1950s when authors such as Burns and Mitchel (1946) attempted to monitor and predict the cyclical development of the economy for the first time. Their Index of Leading Economic Indicators was the basis for creation of other predominant composite indicators (Achuthan \& Banerji, 2004). Since then, composers of composite leading indicators (CLI) have been set up at national and international level. These indicators are ahead of the reference line representing the economic cycle of the selected country (OECD, 2012). The combination of multiple leading indicators allows for a more accurate prediction of the development of the reference series than the prediction indicators alone (Oppenländer, 1997). CLIs are designed to predict the development of the business cycle, which most often represents either the index of industrial production or GDP. CLIs are calculated as the sum of components that cover the key sectors of the economy. They are a simple tool for empirical analysis of the data available (OECD, 2008). CLIs provide timely and relevant information on the current and future economic situation and thus provide 
important help in short-term predictions of changes in the economy (Saltelli, 2006). Priority is the CLI use to identify turnover points in the economic cycle and is intended for economists, economic policy makers of the country and the business community (OECD, 2012). On the basis of the forecast of turnover points, it is possible to respond more flexibly to changes in the economic cycle from an economic policy point of view, which are often delayed, as there is a time gap between the emergence of the measure and its impact on the economy, especially in the case of fiscal policy (Vincúr et al., 1997). For this reason, CLI structures and their analysis are addressed by national statistical authorities, national banks as well as specific enterprises, especially industrial-oriented. CLI has a significant role in the short-term forecasts of the German, UK, US and Japanese economies.

Composite leading indicators also have their disadvantages, and/or limits that are visible in their practical use (which is common for composite indicators, see Djogo \& Stanišić, 2016; RoszkoWójtowicz \& Białek, 2016; Šegota et al., 2017). Their purpose is to introduce balances for CLI partial indicators, a possible incorrect selection of input indicators, and/or poor interpretation of the results. It may seem that the CLI interpretation is relatively simple and straightforward. However, an incorrect interpretation of CLI leads to misleading recommendations for economic policy makers and simplified analytical or policy conclusions.

It is important to note that CLIs offer information about the expected development of the economy, and thus a debate on the implementation of decisions in the public or private sector can be conducted (Monni et al. 2017; Fabuš, 2017; Ciburiene, 2016). This is a short-term estimate of the future economic situation, but it can point to important economic changes which are, in particular, turning points of the economic cycle (Kramoliš, 2015; Mazur, 2017). Berge (2011), in his Spanish case study, found that CLI can more reliably indicate the bottom of the economic cycle (in two-thirds of cases, CLI correctly indicated the bottom) as the peak (half of the peak predictions were correct), i.e. highly likely, but not certainly. For economic policy measures derived from the CLI prediction, it is necessary to be cautious and take into account the impact of several factors, such as the development of CLI partial indicators, the overall nature of the economy, the causes of negative developments (problems of the banking sector, public finances, developments in the credit market, the quality of business environment, economic developments in other countries (depending on the openness of the economy, etc.) (Korsakienè et al. 2017; Travkina, 2015; Sachpazidu-Wójcicka, 2017; Dobeš et al. 2017; Janto-Drozdowska \& Majewska, 2016; Belas \& Sopkova, 2016; Kozubikova et al. 2015; Fuinhas et al., 2016). It is equally important that some fiscal policy decisions can only be positive for the economy in the short term, but in the long run, they may be counterproductive (Korsakienè et al. 2015; Lajtkepová, 2016; Ciegis, 2015).

The prediction of economic cycles and the determination of turnover points are addressed by many economists. For instance, the study by Döpke, et al. (2017) which focuses on the recession prediction in the German economic cycle with the aid of boosted regression trees. Errors in recession forecasting, as it could be seen on the example of Germany, are reported by Drechsel \& Scheufele (2012). Fritche and Kuzim (2005) deal with prediction of turning points in the German economic cycle. Their results indicate that the interest rate spread, the real effective exchange rate as well as some monetary indicators and some survey indicators can help to predict turning points of the German business cycle. Berge (2015) focuses in his study on recession 
forecasting with the help of leading indicators. He argues that predictors that describe a real economic activity provide the clearest signal of recession at very short horizons. In contrast, signals from housing and financial markets produce the best forecasts at longer forecast horizons.

For monitoring of business cycle, it is important to know an actual position of economy (Tendera-Właszczuk \& Szymański, 2015). It is possible with Composite coincident indicators (CCI). Arnoštová, et al. (2011) and Rusnák (2013) develop cyclical indicators for the Czech Republic, and Porshakov, et al. (2015) who build CCI for Russia. Simionescu (2016b) was monitoring economic growth of Romania and V4 and EU member countries (Simionescu et al., 2017b; Simionescu 2016a) and in the collections of authors Simionescu, et al. (2017a), they use combined forecasts to improve survey of profession forecasters' predictions for economy of the USA. On the other hand, Rašić Bakarić, et al. (2011) focus on developing a composite leading indicator, but do not use it for examining the movement of GDP in real time despite having that possibility. Rašić Bakarić, et al. (2016) also constructed CCI for Croatia.

\section{CURRENT COMPOSITE LEADING INDICATORS OF GERMANY}

In the world, institutions such as the OECD, Eurostat and the Conference Board are dedicated to monitoring and short-term predictions of business cycles with CLI. At the national level, it is primarily about banks, but the business sector has also an interest in predicting the economic cycle. For Germany, it is possible to predict the economic cycle using the composite OECD Leading Indicator, the Economic Sentiment Indicator, made by Eurostat and using the indices of national institutions, the Ifo Business Climate Survey and the Zew Index. In all cases, these are composite, i.e. composite indicators made up of several leading indicators of a qualitative or quantitative nature.

\subsection{Composite OECD leading indicator}

The OECD methodology is based on the growth cycle, with the time series spread over random, trend, seasonal and cyclic components. For the trend estimate, the OECD used a modified method of phase-average trend (PAT) of the US National Bureau of Economic Research (NBER) by 2008, which is relatively mathematical and statistically demanding (Boschan \& Ebanks, 1978). It is easy to say that the trend calculation is based on calculating the moving averages of the time series (Nilsson \& Gyomai, 2007). Since December 2008, the OECD has decided to replace the PAT method for the Hodrick-Prescott (HP) filter. The main reason was that the HP filter can remove a trend component in one operation while clearing the entire time series (Schilcht, 2005). Before using the HP filter, the PAT method was also to be supplemented by the Months for cyclical dominance method, which was eliminated by moving averages (OECD, 2008). The advantage of the HP filter is mainly its inability to input data (Bezděk et al., 2003). Beneš and N'Diaye (2004) consider the HP filter as the simplest variant of modern filtering techniques. The HP filter can be applied relatively easily to any time series (Hodric \& Prescott, 1997). In addition, it is necessary to enter only the input parameter $\lambda$, which optimizes trend smoothing (Fabiani \& Mestre, 2000). The disadvantage of the HP filter is the fact that its results are deflected at the beginning and end of the time series. It is so-called „end-points“ issue (Trimbur, 2006). To mitigate this problem, the timeline is supplemented by predictions (Zimková \& Barochovský, 2007). 
For the calculation of the Leading Composite Indicator, the OECD uses monthly data and as of April 2012 uses the monthly GDP data it has calculated as estimates of official quarterly GDP estimates (OECD, 2013). As this calculation of GDP estimates for monthly data has not yet been finalized in all V4 countries, the OECD lists its original CLI databases (Industrial Production Index $(2005=100)$ or its cyclical component) (OECD, 2012).

The OECD, as the only institution, uses indicators related to the external economy as foreign trade, mainly export and exchange rates. In its approach, it combines both soft and hard data. Each indicator has the same weight. The reason why this is the case is that the use of different weights could minimize the impact of indicators that do not show the necessary coincidence with other indicators. As a result, the reliability of composite indicators could be reduced, given that some indicators have greater reporting ability in one cycle and others in another (Gyomai \& Guedette, 2012). According to Nilsson (2000), indicators use OECD better reporting value than the indicators used by the European Union.

For the OECD, it is typical that each country has a different composition of the leading indicator depending on the specifics of the economy. The resulting OECD-generated composite indicator of Germany has the following components (OECD, 2017):

- IFO business climate indicator (normal=100),

- Orders inflow/demand (manuf.): tendency (\% balance),

- Export order books (manuf.): expectation (\% balance),

- New orders in manuf. industry $(2010=100)$,

- Finished goods stocks (manuf.): level (\% balance) inverted,

- Spread of interest rates (\% p.a.).

\subsection{Economic sentiment indicator of Eurostat}

Eurostat methodology is based on confidence indicators created by the European Commission for the Euro area. This approach is based on the monitoring of approximately 12500 companies and 40000 consumers surveyed and these surveys are carried out periodically at monthly intervals since 1961. The main advantage of these data is that they are available much earlier than the classic "hard data" coming from national accounts or output of the economy. For instance, while the European Commission releases business and consumer survey data at the end of the period, the estimate of the consumer confidence index is still about 10 days earlier (European Commission, 2015). Eurostat's composite leading indicator, the Economic Sentiment Indicator (ESI), in the short-term statistics, summarizes the development of the economy in the five sectors covered by confidence indicators. Thus, the Eurostat, unlike the OCED, creates a composite indicator that has the same components for all countries with the following weights:

- confidence indicator in industry - 40\%,

- confidence indicator in the service - 5\%,

- consumer confidence indicator - 30\%,

- confidence indicator in construction - 20\%,

- confidence indicator in retail - 5\%. 
The list of weights listed above is based on two criteria: a representativeness of the sector concerned and a performance monitoring against the reference line on the GDP growth.

\subsection{Ifo Business Climate Survey}

Ifo Institute - Ifo Institute for Economic Research (Munich Institute of Economic Research) developed a monthly business climate index - Ifo Business Climate Survey. It is a leading indicator measuring the performance of the German economy. This is a key indicator, as the business climate of Germany as the largest economy in the EU also affects the rest of the EU. Ifo is based on about 7000 results of regular monthly surveys of companies in the manufacturing, construction, wholesale and retail sectors. The Institute has conducted these surveys since January 1991. East and West Germany have separate indices, but the West German index represents Germany as a whole (Wirtschaftswoche, 2017).

\subsection{ZEW index}

The ZEW index is a leading indicator of economic health, as changes in opinion and mood may change future economic activity (Obrex, 2016). In the ZEW index, this is a monthly survey where about 350 experts from banks, insurance companies and financial institutions surveyed about their medium-term expectations regarding the economic development and development of the captain's market. Respondents respond to questions about inflation, interest rates, exchange rates, and developments in the stock market for the next 6 months. As with the IFO index, there are only three answers: positive, negative, without change (ZEW Finanzmarktreport, 2017). The main advantage of the ZEW indicator is that results can be published between one and one and a half weeks after the data is collected. This is, according to Oppenländer (1997), the main reason that the data from these surveys should have the same value as quantitative data. Interpretation of the resulting indicator is relatively simple. The resulting index above zero reflects a positive outlook on economic development if it is greater than 0 and negative if it is less than 0 . ZEW is primarily focused on the German economy, as Germany, as one of the strongest economies, also shows the economy of the entire euro area (ZEW Konjunkturreport, 2001). It is also possible to derive an estimate of the direction of the German economic cycle from this index. The ZEW indicator has an advance of 6 months (Handbuch, 2015). Also known is Early-Bird-Indicator, which is created by Commerzbank, which is about two months ahead of ZEW and 3-4 months over IFO. This is an indicator reported with a weekly periodicity (Hinze, 2003).

\section{OBJECTIVES AND RESEARCH METHODOLOGY}

The aim of the paper is to propose a composite leading indicator for monitoring the German economic cycle and to compare its prediction capabilities with the available leading indicators for Germany. For analysis purposes, the CLI creation methodology is developed using a combination of OECD and Infostat methodologies. The methodology is built to work with the growth cycle. For the reference line, it is possible to choose a GDP indicator or industrial production index that represents Germany's economic cycle. Among the indicators related to GDP are 140 quantitative and qualitative indicators of industry, services, retail, construction, foreign trade, labor market, money aggregates, stock indices, confidence indicators, consumer expectations as 
well as GDP components alone. Government spending on final consumption has already proved to be a strong lead indicator in relation to GDP (Mihóková \& Jakubíková, 2011). The IFO index was included among the indicators, as the OECD also considered it an important CLI component for the German economy. Data sources include the OECD, Eurostat, National Bank of Germany, the European Central Bank and the German Statistical Office. In all cases, this is data with a quarterly periodicity. The time series are initially seasonally cleaned using the seasonal indexing method, and the trend is then removed using the Hodrick-Prescott filter (HP filter) in the R program. The HP filter in one operation will also provide for the elimination of the timeline in addition to the removal of the time series (Schilcht, 2005; Kovacic \& Vilotic, 2017). To determine the relationship between the variables, cross-correlation (Pearson correlation coefficient) with five forward and backward shifts in MS Excel is used. For the CLI construction, it is important to obtain a set of leading cyclical indicators from the 140 economic indicators. The precondition for cyclical indicators is the position of the highest cross-correlation value at time $\mathrm{t}-1$ to $\mathrm{t}-5$ and the value of the second highest cross correlation value at a level of at least 0.55 . The selection and scoring method followed by the following criteria (Klúčik, 2009) is then used to select prediction indicators:

- Economic significance (10b): share in the economy as a whole (5b), economic interpretation (5b),

- Statistical significance (30b): correlation coefficient (10b), number of upward quarters (10b), smoothness of time series (3b), identification of turn points (7b),

- Statistical quality (10b): timeliness (5b), smoothness (3b), authenticity (2b).

Due to the different sub-unit units, their normalized values obtained using the Standardization Method (OECD, 2008) is used for CLI. A system of the same and different weights is used. The same scales are used by both the CLI and the OECD. The relationship is used to determine the same weights:

$$
v=1 / n
$$

where $v$ is the weight for each leading cyclical indicator and $n$ is the number of leading cyclical indicators entering the CLI. To determine the system of different weights, the cross-correlation value is used at the time of the overtime, that is, the greater the cross-correlation value, the greater weight the predominant cyclical indicator in the CLI. Different scales can be calculated in the form of a relationship:

where $v_{i}$ is the weight for the $i$-th prediction indicator, $r_{i}$ is the highest cross-correlation value of the prediction cyclical indicator at the time of overtaking, and $n$ is the number of pre-cyclical

$$
v_{i}=\frac{r_{i}}{\sum_{i=1}^{n} r_{i}}
$$

indicators entering the CLI. For the CLI construction at a given time, it is necessary to create a sum of normalized values of the pre-cyclical indicators multiplied by the weights associated with them. The prediction size of the CLI generated before the GDP reference range is again realized with the help of a cross correlation, with the highest cross-correlation value at time t- 1 to 
t-5. The correctness of the CLI composition can be verified by including a predominant cyclical indicator with the smallest cross-correlation value from the group of leading indicators selected by selection and scoring methods. For instance, CLI calculations can produce composite indicators composed of seven to three partial prediction cyclical indicators. Cross-correlation values with different CLI components thus determine the best CLI variant that has the most predictive ability at a given time. To verify the effect of the time line length on the composition of the CLI, seven basic ones are specified.

\section{Construction of Germany's composite leading indicator}

\section{Choice of the reference series}

It is essential to select a reference range that would adequately represent the economic cycle in Germany for creating CLI. Based on the theoretical backgrounds, GDP or industrial production index can be used. Cross-correlation values for the cyclical components of these indicators are shown in Table 1.

Tab. 1 - Cross-correlation results between GDP and IPP (Q1 2000 - Q4 2016). Source: own processing

\begin{tabular}{|l|c|c|c|c|c|c|c|c|c|c|c|}
\hline Indicator & $\mathrm{t}-5$ & $\mathrm{t}-4$ & $\mathrm{t}-3$ & $\mathrm{t}-2$ & $\mathrm{t}-1$ & $\mathrm{t}$ & $\mathrm{t}+1$ & $\mathrm{t}+2$ & $\mathrm{t}+3$ & $\mathrm{t}+4$ & $\mathrm{t}+5$ \\
\hline $\begin{array}{l}\text { Cross- } \\
\text { Correla- } \\
\text { tion value }\end{array}$ & -0.097 & 0.134 & 0.402 & 0.650 & 0.860 & 0.946 & 0.798 & 0.540 & 0.252 & -0.022 & -0.263 \\
\hline
\end{tabular}

There is a strong relationship between the cyclical component of GDP and the Industrial Production Index, which represents the cross correlation value at 0.946 at time t. This means that both indicators are appropriate for monitoring and predicting the German economic cycle with a quarterly periodicity. The second cross correlation value is at time $\mathrm{t}-1$. This may mean that monthly GDP and IIP developments are slightly ahead of GDP by two or three months. The development of cyclic components of both indicators is illustrated in Figure 1.

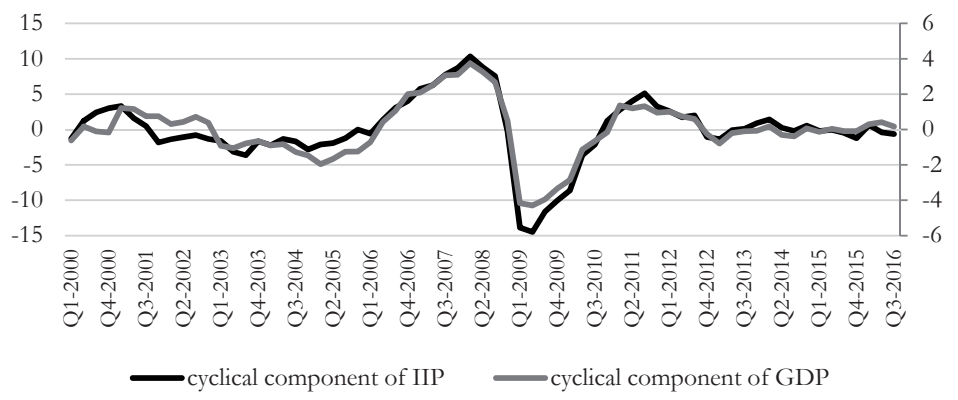

Fig. 1 - Development of the cyclical component of GDP and the cyclical component of IPP, 2000 - 2016. Source: Own processing 
For CLI of Germany, it is advisable to select either the GDP or the industrial production index for the reference range. Both indicators can fully represent the German economic cycle. For the CLI needs, the selected GDP reference series is used to improve CLI comparability with the CLI of OECD and Eurostat views, which are currently considered by GDP to be the best indicator for monitoring the EU economic cycle.

\section{Selection of pre-cyclical indicators}

In the case of Germany, 140 time series from different areas of the economy were monitored. Using the chosen methodology, 18 indicators were selected, which behaved as leading cyclical indicators. These were industry indicators, stock indices, components of the economic sentiment index, and the IFO index. Subsequently, a selection and scoring method was applied, which reduced the set of leading cyclic indicators to seven, as can be seen in Table 2.

Tab. 2 - Predictive cyclical indicators based on the selection and scoring method for the period 2000 - 2016. Source: own processing

\begin{tabular}{|l|l|l|l|l|l|l|}
\hline Indicator & $\mathrm{t}-5$ & $\mathrm{t}-4$ & $\mathrm{t}-3$ & $\mathrm{t}-2$ & $\mathrm{t}-1$ & $\mathrm{t}$ \\
\hline IFO index & 0.355 & 0.539 & 0.702 & 0.804 & 0.786 & 0.597 \\
\hline Primary earnings, credit & 0.343 & 0.565 & 0.691 & 0.726 & 0.660 & 0.548 \\
\hline $\begin{array}{l}\text { Turnover in industry, inter- } \\
\text { mediate production, overall } \\
\text { market }\end{array}$ & 0.869 & 0.958 & 0.795 & 0.518 & 0.212 & -0.080 \\
\hline $\begin{array}{l}\text { Expectations of the number } \\
\text { of orders made by suppliers } \\
\text { over the next 3 months }\end{array}$ & 0.271 & 0.476 & 0.681 & 0.807 & 0.790 & 0.621 \\
\hline Stock price index & 0.238 & 0.450 & 0.604 & 0.701 & 0.716 & 0.585 \\
\hline $\begin{array}{l}\text { Confidence indicator in } \\
\text { industry }\end{array}$ & 0.283 & 0.455 & 0.615 & 0.739 & 0.773 & 0.638 \\
\hline $\begin{array}{l}\text { Consumer confidence } \\
\text { indicator }\end{array}$ & 0.241 & 0.455 & 0.639 & 0.785 & 0.837 & 0.750 \\
\hline
\end{tabular}

A qualitative and quantitative data was included in the group of cyclical indicators that most predominated in Germany's economic cycle. It was a stock index, components of the economic sentiment indicator and industry indicators. Also, the IFO index, which is a component of the OECD CLI, also appeared.

\section{The composition of CLI of Germany and verification of its predictive abilities}

Seven selected indicators were subjected to further investigation to see if it is an optimal combination of indicators. An up-front indicator with the smallest cross-correlation value was sequentially collected, resulting in five CLIs with different compositions as shown in Table 3. 
Tab. 3 - Combinations of CLI components. Source: own processing

\begin{tabular}{|l|l|}
\hline CLI & Composition of CLI \\
\hline CLI 1 & $\begin{array}{l}\text { IFO index } \\
\text { Turnover in industry, intermediate production, overall market } \\
\text { Expectations of the number of orders made by suppliers over the next 3 } \\
\text { months } \\
\text { Consumer confidence indicator } \\
\text { Confidence indicator in industry } \\
\text { Primary earnings, credit } \\
\text { Stock price index }\end{array}$ \\
\hline CLI 2 & CLI 1 - Stock price index \\
\hline CLI 3 & CLI 2 - Primary earnings, credit \\
\hline CLI 4 & CLI 3 - Confidence indicator in industry \\
\hline CLI 5 & $\begin{array}{l}\text { CLI } 4-\text { Expectations of the number of orders made by suppliers over the next } \\
3 \text { months }\end{array}$ \\
\hline
\end{tabular}

For the CLI construction, the cyclic components were normalized and a system of the same weights was then used. A CLI time series composed of various components based on Table 3 was created. Table 4 shows Cross-correlations of CLI 1-5 and the cyclical component of GDP for Germany in Q1 2000 - Q4 2016.

Tab. 4 - Cross-correlation results between CLI and GDP, equal weight, Q1 2000 - Q4 2016. Source: own processing

\begin{tabular}{|l|l|l|l|l|l|l|}
\hline Indicator & $\mathrm{t}-5$ & $\mathrm{t}-4$ & $\mathrm{t}-3$ & $\mathrm{t}-2$ & $\mathrm{t}-1$ & $\mathrm{t}$ \\
\hline CLI 1 & 0.444 & 0.665 & 0.807 & 0.867 & 0.815 & 0.625 \\
\hline CLI 2 & 0.465 & 0.678 & 0.812 & 0.863 & 0.799 & 0.605 \\
\hline CLI 3 & 0.465 & 0.663 & 0.790 & 0.841 & 0.782 & 0.581 \\
\hline CLI 4 & 0.508 & 0.710 & 0.824 & 0.853 & 0.768 & 0.552 \\
\hline CLI 5 & 0.575 & 0.766 & 0.838 & 0.827 & 0.720 & 0.497 \\
\hline
\end{tabular}

From Table 4, it can be seen that the best predictive ability is CLI composed of all seven components obtained by the selection and scoring method. CLI 1 assembled with the same weight system has prediction capabilities of two quarters with a cross correlation value of 0.867 . The final relationship for CLI of Germany using the same weights looks as follows:

$$
\begin{aligned}
& \text { CLI 1=1/7*IFO }+0,143^{*} \text { primary earnings, credit } \\
& +0,143^{*} \text { turnover in industry }+0,143^{*} \text { expected number of orders } \\
& +0,143^{*} \text { stock price index }+0,143^{*} \text { confidence indicator in industry } \\
& +0,143^{*} \text { consumer confidence indicator }
\end{aligned}
$$

Consequently, a system of different weights was used using the cross correlation values of the precyclical indicators. To differentiate CLI at different scales, the letters (1-A, 2-B, 3-C, 4-D , 5-E) were used instead of the numerals. Cross correlation values for different weights are shown in Table 5 . 
Tab. 5 - Cross-correlation results between CLI and GDP, different weights, 2000 - 2016.

Source: own processing

\begin{tabular}{|l|l|l|l|l|l|l|}
\hline Indicator & $\mathrm{t}-5$ & $\mathrm{t}-4$ & $\mathrm{t}-3$ & $\mathrm{t}-2$ & $\mathrm{t}-1$ & $\mathrm{t}$ \\
\hline CLI A & 0.467 & 0.686 & 0.818 & 0.867 & 0.805 & 0.607 \\
\hline CLI B & 0.488 & 0.699 & 0.823 & 0.862 & 0.788 & 0.587 \\
\hline CLI C & 0.491 & 0.688 & 0.805 & 0.842 & 0.771 & 0.563 \\
\hline CLI D & 0.533 & 0.733 & 0.836 & 0.850 & 0.754 & 0.531 \\
\hline CLI E & 0.602 & 0.791 & 0.849 & 0.821 & 0.701 & 0.470 \\
\hline
\end{tabular}

Using different weights did not significantly change the strength or predictive size of the CLI A-E composition. Again, it has achieved the best CLI A results, which has the same composition as CLI 1. CLI A shows two quarters with a cross correlation value of 0.867 . The resulting relationship for the CLI A calculation is as follows:

$$
\begin{aligned}
& \text { CLI A }=0,144^{*} I F O+0,130 * \text { primary earnings } \\
& +0,172 * \text { turnover in industry } \\
& +0,14{ }^{*} \text { expectations of number of orders } \\
& +0,126^{*} \text { stock price index } \\
& +0,133{ }^{*} \text { confidence indicator in industry } \\
& +0,150{ }^{*} \text { consumer confidence indicator }
\end{aligned}
$$

Using the same and different weights with the help of the cross-correlation values of each CLI component, CLI predicted a change in predictive capabilities. For the purposes of further investigation, the CLI 1 time series is used at the same weight for Q1 2000 - Q4 2016. The prediction capabilities of CLI 1 against Germany's economic cycle can also be seen in Figure 2.

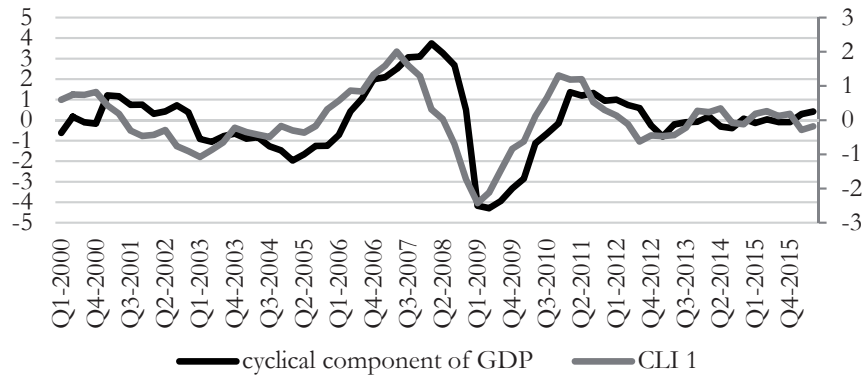

Fig. 2 - Development of the cyclical component of GDP and CLI 1, period 2000 - 2016. Source: own processing

Figure 2 shows the predictive capabilities of CLI 1 in relation to the development of Germany's economic cycle. It is most noticeable to observe before the crisis in 2008, when CLI 1 predicted a decline in the economy, bottom and subsequent recovery with sufficient time in advance. 


\section{Comparison of the CLI created with the existing Eurostat and OECD indicators}

Based on the available databases, it is possible to compare CLI 1 with CLI of OECD and the economic sentiment indicator used by Eurostat to predict economic cycles. The composition of the individual overhead indicators, the size and the overtime were compared, as shown in Table 6.

Tab. 6 - Comparison of CLI composition for Germany by organization over 2000 - 2016.

Source: own processing

\begin{tabular}{|c|c|c|c|}
\hline Indicator & CLI 1 & CLI, OECD & ESI, Eurostat \\
\hline $\begin{array}{l}\text { Cross-correlation } \\
\text { value over time }\end{array}$ & 0.867 & 0.718 & 0.699 \\
\hline $\begin{array}{l}\text { Size ahead in quar- } \\
\text { ters }\end{array}$ & $\mathrm{t}-2$ & $\mathrm{t}-2$ & $\mathrm{t}-2$ \\
\hline Composition & $\begin{array}{l}\text { IFO index, } \\
\text { Primary earnings, } \\
\text { credit, } \\
\text { Turnover in industry, } \\
\text { intermediate produc- } \\
\text { tion, overall market, } \\
\text { Expectations of the } \\
\text { number of orders } \\
\text { made by suppli- } \\
\text { ers over the next } 3 \\
\text { months, } \\
\text { The stock price } \\
\text { index, } \\
\text { The confidence } \\
\text { indicator in industry, } \\
\text { Consumer confi- } \\
\text { dence indicator. }\end{array}$ & $\begin{array}{l}\text { IFO index, } \\
\text { Orders inflow/de- } \\
\text { mand, } \\
\text { Export order books, } \\
\text { New orders in } \\
\text { manuf. Industry, } \\
\text { Finished goods } \\
\text { stocks, } \\
\text { Spread of interest } \\
\text { rates. }\end{array}$ & $\begin{array}{l}\text { The confidence indi- } \\
\text { cator in industry, } \\
\text { The confidence indi- } \\
\text { cator in the service, } \\
\text { Consumer confi- } \\
\text { dence indicator, } \\
\text { The confidence indi- } \\
\text { cator in construction, } \\
\text { Confidence indicator } \\
\text { in retail. }\end{array}$ \\
\hline
\end{tabular}

Table 6 shows that CLI 1 has the highest cross correlation value (0.867), which means that it can predict the evolution of Germany's economic cycle with the smallest number of false signals. In the case of an overdose, the highest cross-correlation value was reached for all indicators at time $\mathrm{t}-2$, which represents an advance of two quarters. CLI 1 consists of common indicators with CLI of OECD and ESI of Eurostat. For example, CLI 1 includes the IFO Business Environment Index, which is a high-quality indicator used to predict the German economy. The OECD includes it among the components of OECD's CLI. The IFO index itself, however, can predict the German economic cycle two quarters in advance with a cross-correlation value of 0.804 . This value is higher than for the whole CLI of OECD or ESI of Eurostat. The analysis confirmed the significance of the IFO index and was therefore included in the resulting CLI 1 indicator. The impact of the economic sentiment indicator, used by Eurostat to predict economic cycles, was also confirmed. CLI 1 included ESI components, the industry confidence indicator and the 
consumer confidence indicator. The prediction capabilities of CLI 1, CLI of OECD and ESI are also visible in Figure 3.

Based on the results of cross-correlations and also on the graphical development of the forecasted indicators, it is possible to confirm the prediction capabilities of CLI 1, CLI of OECD and ESI of Eurostat. Each indicator is able to sufficiently predict the development of the German economic cycle. However, the combination of the qualitative and quantitative data offered by CLI 1 is the best.

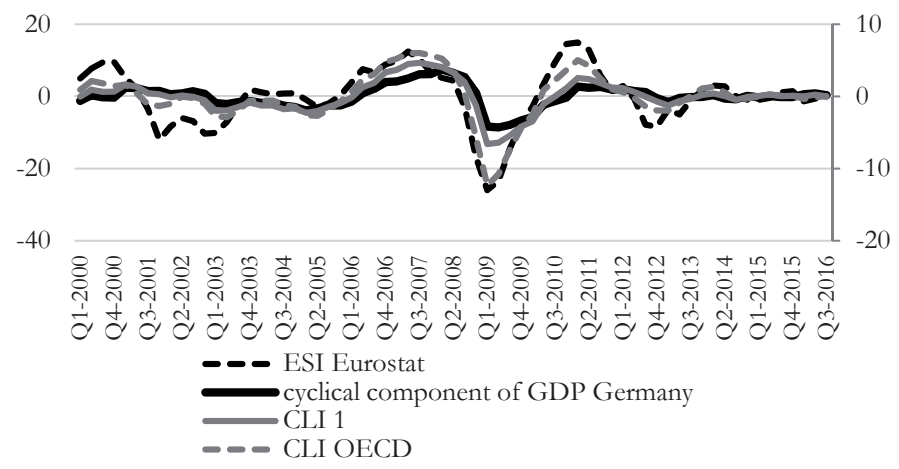

Fig. 3 - Graphical development of indicators produced by different organizations and their comparison with GDP development. Source: own processing

\section{Forecasting the development of the German economy with CLI 1}

The main objective of composite leading indicators is creation of a current prediction of the cyclical development of the economy. For this reason, the available values of the cyclical component of GDP for the period from Q4 2016 to Q3 2017 (OECD estimate) have been added. For the same period, CLI 1 was also created for the German economy. CLI 1 is presented in Table 3. Subsequently, the CLI 1-time series from Q1 2000 to Q3 2017 was supplemented by prediction using the extrapolation method. The prediction also solved the "ending problem" that arises from using the HP filter. CLI 1 values were predicted for Q4 2017 and Q1 2018. The resulting values are shown in Figure 4.

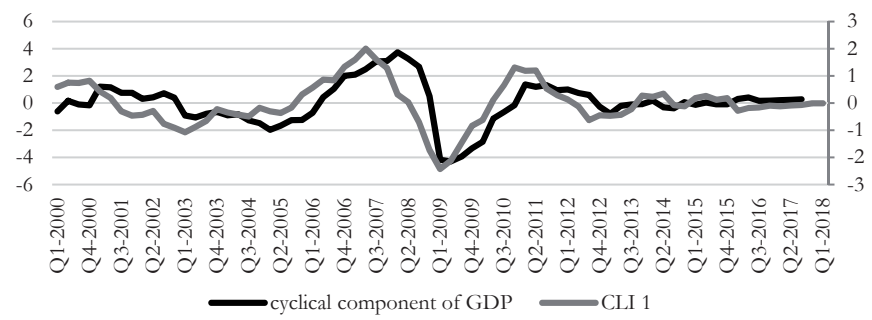

Fig. 4 - Graphical development of cyclical component of GDP Germany and forecasting CLI 1. Source: own processing 
The predicted CLI 1 values point to a moderate economic growth of the German economy in Q4 2017 and Q1 2018. This is confirmed by the IFO index and the expectations of the financial markets that anticipate the continuing economic growth of the German economy. Growth in the economy is also confirmed by a positive economic development of the Economic Sentiment Index reported by Eurostat. The potential for economic growth can be expected under the influence of growth in domestic demand and investment. GDP growth also has a positive impact on government spending. A good sign for the German economy is also accelerating inflation and the likelihood that the European Central Bank will change its extremely relaxed monetary policy.

\section{DISCUSSION}

On the basis of the analysis of selected economic indicators, a composite leading indicator was set up, which is suitable for the short-term prediction of the German economic cycle. The generated CLI 1 can predict the German economy two quarters ahead with a cross correlation value of 0.867. This result is better than the CLI of OECD, the ESI of Eurostat, or the IFO index created by the Ifo Institute for Economic Research. CLI 1, however, it confirms that a combination of selected OI components, OICs, IFOs, and ESI components creates a suitable combination for creating a high-quality composite indicator. Therefore, it is appropriate to use a combination of qualitative and quantitative data for CLI creation, which results in more accurate results and it minimizes the number of false signals about the future development of the economy. Based on the historical data analysis, it was confirmed that composite leading indicators can be considered a good tool for monitoring and predicting economic cycles. At the time of the financial crisis, the CLI has been able to anticipate an economic downturn, identify the bottom and the subsequent economic recovery. It is possible to prepare early for fluctuations in the economic activity and to propose measures mainly in the area of fiscal policy on the basis of the CLI. Politicians thus know the estimates of the future development of Germany's economy and can reach an expansive or restrictive fiscal stance that directly affects the state of public finances in the country. Predicting future business cycle development with CLI helps minimize the time gap between the state of the economy and the introduction of the fiscal measure into practice. At the time of the expected expansion, politicians can reduce state resources and work on a balanced or surplus budget. Expectations of recession may lead to a rise in government spending that would help rebuild the economy in the short run. Entrepreneurs are more responsive to forecasts of economic development in the country, so it should also be in the interest of the state to predict the development of the economy as highest quality as possible. With positive predictions, the business sector is in a tune with the growth of investment and the recruitment of new labor, leading to further economic growth in the country. In negative predictions, entrepreneurs are much more sensitive to new investment projects and they are looking for less risky areas. It confirmed also Hudakova et al. (2017). However, CLI's relationship with investor expectations is double-sided. Even in Germany, it has been shown that these expectations have an important role to play in predicting the future economic development of the German economy. The German economic cycle should see a slight increase in the near future, which should encourage the business sector to increase investment not only in Germany but also in other linked economies, such as Slovakia. In the case 
of this pro-export-oriented economy, the development of the German economic cycle should be reflected in the Slovak economic cycle with a lag of one to two quarters. It is also important to note that CLI only provides some estimates of future developments. It is not an accurate prediction of GDP values. Therefore, it is necessary to combine several indicators suitable for prediction of the economic cycles. Based on our analysis, all composite indicators, CLI of OECD, ESI and IFO, may be recommended.

\section{CONCLUSIONS}

The composite leading indicators are of appropriate choice for the purposes of monitoring and prediction of business cycles. Their structure is addressed by international institutions such as the OECD, Eurostat as well as institutions at the national level. Created composite indicators differ in the methodology of calculation and composition itself. While the OECD prefers an individual approach to CLI creation, Eurostat uses the Economic Sentiment Indicator for all community countries. Germany's IFO and ZEW indices are also known for Germany, which can predict the development of the German economic cycle on a monthly basis. Based on the methodology chosen, a new composite indicator for Germany was constructed. Out of 140 monitored indicators, the resulting CLI consists of seven components of the industry, stock index, IFO index and the economic sentiment indicator components. Using the cross correlation, the prediction capabilities of the constructed CLI were verified, confirming its two-quarter prediction with a cross-correlation value above 0.8 . The predictive capabilities of the CLI created were even better than the CLI of OECD, Eurostat and IFO. It is, however, advisable to use a combination of multiple CLIs to predict the German economic cycle, thereby minimizing the number of false signals.

\section{References}

1. Achutchan, L., \& Banerji, A. (2004). Beating the Business Cycle: How to Predict and Profit from Turning Points in the Economy. London: Crown Business.

2. Arnoštová, K., Havrlant, D., Růžička, L., \& Luboš, T. P. (2011). Short-term forecasting of Czech quarterly GDP using monthly indicators. Finance a Uver, 61 (6), 566-583.

3. Belas, J., Sopkova, G. (2016). A Model of Entrepreneurial Orientation. Transformation in Business \& Economics, 15 (2B), 630-645.

4. Beneš, J., \& N’ Diaye, P. (2004). A Multivariate Filter for Measuring Potencial Output and the NAIRU: Application to the Czech Republic. Working Paper No. 04/45. IMF. Retrieved January 1, 2017, from http://www.imf.org/external/pubs/ft/wp/2004/wp0445.pdf.

5. Berge, T. J. (2011). A Chronology of Turning Points in Economic Activity: Spain 1850-2011. SERIEs, 4(1), 1-34.

6. Berge, T. J. (2015). Predicting Recessions with Leading Indicators: Model Averaging and Selection over the Business Cycle. Journal of Forecasting, 34(6), 455-471. https://doi. org/10.1002/for.2345. 
7. Bezděk, J., Dybczak, A., \& Krejdl, A. (2003). Czech Fiscal Policy: Introductory Analysis. Czech National Bank, Working Paper 2003-7.

8. Boschan, C., \& Ebanks, W.W., (1978). The Phase Average Trend: A new way of Measuring Economic Growth. Proceeding of the business and economic statistics section.

9. Burns, A. F., \& Mitchell Weslay, C. (1946). Measuring Business Cycles. Cambridge: National Bureau of Economic Research.

10. Businessdictionary (2016). ZEW Economic Sentiment. Retrieved December 26, 2016, from http://www.businessdictionary.com/definition/ZEW-Economic-Sentiment.html.

11. Ciegis, R., Aidas Dilius, A., \& Asta Mikalauskiene, A. (2015). Evaluation od Economic Growth in Terms of Sustainability. Transformation in Business and Economics, 14 (1). 105-125.

12. Dobeš, K., Kot, S., Kramoliš, J., \& Sopková, G. (2017). The Perception of Governmental Support in The Context of Competitiveness of SMEs in the Czech Republic. Journal of Competitiveness, 9 (3), 34-50. https://doi.org/10.7441/joc.2017.03.03.

13. Djogo, M. \& Stanišić, N. (2016). Is the Global Competitiveness Report the right measure of macroeconomic competitiveness? Proceedings of Rijeka Faculty of Economics: Journal of Economics and Business, 34 (1), 91-117.

14. Döpke, J., Fritsche, U., \& Pierdzioch, C. (2017). Predicting recessions with boosted regression trees. International Journal of Forecasting, 33(4), 745-759. https://doi.org/10.1016/ j.ijforecast.2017.02.003.

15. Drechsel, K., \& Scheufele, R. (2012). The financial crisis from a forecaster's perspective. Kredit und Kapital, 45(1), 1-26. https://doi.org/10.3790/kuk.45.1.1.

16. European Commission (2015). Short-term business statistics and the economic sentiment indicator. Retrieved December 20, 2016, from http://ec.europa.eu/eurostat/statisticsexplained/index.php/Shortterm_business_statistics_and_the_economic_sentiment_ indicator.

17. Fabiani, S., \& Mestre, R., (2000). Alternative Measures of the NAIRU in the Euro area: Estimates and assessment. European Central Bank, Working Paper 2000-17.

18. Fabuš, M. 2017. Current development of business environment in Slovakia and Czech Republic. Entrepreneurship and Sustainability Issues, 5(1), 127-137. https://doi.org/10.9770/ jesi.2017.5.1(10).

19. Fritsche, U., \& Kuzin, V. (2005). Prediction of Business Cycle Turning Points in Germany / Prognose konjunktureller Wendepunkte in Deutschland. Jabrbücher Für Nationalökonomie Und Statistik, 225(1). https://doi.org/10.1515/jbnst-2005-0103.

20. Fuinhas, J. A., Marques, A. C., Almeida, P., Nogueira, D., Branco, T. (2016). Two Centuries of Economic Growth: International Evidence od Deepness and Steepness. Transformation in Business and Economics, 15 (3), 192-206.

21. Gyomai, G., \& Guidetti, E. (2012). OECD System of Composite Leading Indicators. Paris: Organization for Economic Cooperation and Development. Retrieved April 24, 2016, from http://www.oecd.org/std/leading-indicators/41629509.pdf. 
22. Helba Handbuch (2015). Wirtschaftsindikatoren unter der Lupe. Research. April, 2015. Retrieved January 5, 2017, from https://www.helabade/blob/helaba/289852/ ae021831757 d9bbe34c 41131e78eba03/report---helaba-handbuch—wirtschaftsindikatoren.

23. Hinze, J. (2003). Prognoseleistung von Frühindikatoren. Die Bedeutung von Frühindikatoren für Konjunkturprognosen - Eine Analyse für Deutschland. HWWA Discussion paper No. 236. Hamburg: HWWA. Retrieved December 10, 2016, from http:// ageconsearch.umn.edu/bitstream/26253/1/dp030236.pdf.

24. Hodric, R. J. \& Prescott, E. C. (1997). Postwar U.S. Business cycles: an Empirical Investigation. Journal of Money, Credit and Banking, 29 (1), 1-16.

25. Hudakova, M., Schonfeld, J., Dvorsky, J., \& Luskova, M. (2017). The Market Risk Analysis and Methodology of its More Effective Management in Smes in the Slovak Republic. Montenegrin Journal of Economics, 13 (2),151-161. https://doi.dx.org/10.14254/18005845/2017.13-2.10.

26. Investopedia (2017). Ifo Business Climate Survey. Retrieved December 10, 2016, from http://www.investopedia.com/terms/i/ifo-business-climate-survey.asp.

27. Jantoń-Drozdowska, E., \& Majewska, M. (2016). Investment attractiveness of Central and Eastern European countries in the light of new locational advantages development. Equilibrium. Quarterly Journal of Economics and Economic Policy, 11(1): 97-119. https://doi.org/ https://doi.org/10.12775/EQUIL.2016.005.

28. Kl'účik, M. (2009). Composite Reference Series and Composite Leading Indicator for Slovakia. The First Macroeconomic Forecasting Conference - MFC, Rome.

29. Kramoliš, J. (2015). Design as a Condition for Prosperity in Czech Businesses - A Comparative Study. Journal of Competitiveness, 7 (4), 33-47. https://doi.org/10.7441/ joc.2015.04.03.

30. Konovalova, N., Kristovska I., \& Kudinska, M. (2016). Credit Risk Management in Commercial Banks. Polish Journal of Management Studies, 13 (2), 90-100. https://doi. org/10.17512/pjms.2016.13.2.09.

31. Korsakienė, R.; Liučvaitienè, A.; Bužavaitė, M.; \& Šimelytė, A. (2017). Intellectual capital as a driving force of internationalization: a case of Lithuanian SMEs. Entrepreneurship and Sustainability Issues 4(4), 502-515. https://doi.org/10.9770/jesi.2017.4.4(8).

32. Korsakienè, R.; Diskienė, D.; \& Smaliukiené, R. (2015). Institutional theory perspective and internationalization of firms. How institutional context influences internationalization of SMES? Entrepreneurship and Sustainability Issues, 2(3). https://doi.org/10.9770/ jesi.2014.2.3(3).

33. Kovacic, Z. \& Vilotic, M. (2017). Characterising and testing European business cycles asymmetry. Equilibrium. Quarterly Journal of Economics and Economic Policy, 12(3): 453-468. https://doi.org/https://doi.org/10.24136/eq.v12i3.24.

34. Kozubikova, L., Belas, J., Kljucnikov, A., Virglerova, Z. (2015). Differences in approach to selected constructs of entrepreneurail orientation in SME segment regarding the selected socio-demographic factors. Transformation in Business nad Economic, 14 (3C), 333-355. 
35. Lajtkepová, E. (2016). Differences and similarities in the indebtedness of EU member states after last financial crisis. Oeconomia Copernicana, 7(4): 551-563. https://doi.org/https:// doi.org/10.12775/OeC.2016.031.

36. Mazur, B. (2017). Probabilistic predictive analysis of business cycle fluctuations in Polish economy. Equilibrium. Quarterly Journal of Economics and Economic Policy, 12(3): 435-452. https://doi.org/https://doi.org/10.24136/eq.v12i3.23.

37. Mitrová, K. (2017). Predstihový kompozitný indikátor Nemecka. Diplomová práca. Košice: Technická univerzita v Košiciach.

38. Monni, S.; Palumbo, F.; \& Tvaronavičienè, M. (2017). Cluster performance: an attempt to evaluate the Lithuanian case. Entrepreneurship and Sustainability Issues, 5(1), 43-57. https://doi. $\operatorname{org} / 10.9770 /$ jesi.2017.5.1(4).

39. Mihóková, L, \& Jakubíková, E. (2011). Impact of the Government Debt on the Macroeconomic Development of the Slovak and Chech republic. In: L. Vitek (Ed.). Analysis of the Impact of the Economic Crisis of Public Finances. Praha: Wolters Kluwer ČR, 116-141.

40. Nilsson, R. (2000). Confidence Indicators and Composite Indicators. Paris CIRET Conference of Organization for Economic Cooperation and Development.

41. Nilsson, R., \& Gyomai, G. (2011). Cycle Extraction: A Comparison of the Phase-Average Trend Method, the Hodrick-Prescott and Christiano-Fitzgerald Filters. OECD statistics working papers 39. http://dx.doi.org/10.1787/5kg9srt7f8g0-en.

42. OECD (2008). Handbook on Constructing Composite Indicators: Methodology and User Guide. Paris: OECD Publishing.

43. OECD (2012). OECD System of Composite Leading Indicator. Retrieved January 4, 2017, from http://www.oecd.org/std/leading-indicators/41629509.pdf.

44. OECD (2017). Composite Leading Indicators: Turning Points of Reference Series and Component Series. Retrieved April 3, 2017, from https://www.oecd.org/std/leading-indicators/CLIcomponents-and-turning-points.pdf.

45. OECD (2013). Main economic indicator: Composite leading indicators. Paris: OECD Publishing.

46. Oppenländer, K. H. (1997). Characteristics and Classifications of Business Cycle Indicators. United Kingdom: Avebury.

47. Orbex. (2016). What Is ZEW Economic Sentiment Index \& Levels to Watch. Retrieved December 25, 2016, from https://www.orbex.com/blog/2016/10/what-is-zew-economic-sentiment-index

48. Porshakov, A., Deryugina, E., Ponomarenko, A., \& Sinyakov, A. (2015). Nowcasting and short-term forecasting of Russian GDP with a dynamic factor model. BOFIT Discussion papers, 19/2015.

49. Rusnák, M. (2013). Nowcasting Czech GDP in real time. Working Papers 2013/6, Czech National Bank.

50. Rašić Bakarić, I., Tkalec, M., \& Vizek, M. (2011). Application of model-based approach to the calculation of the leading composite indicator: The case of CROLEI inde. Ekonomski pregled, 62 (11), 613-635. 
51. Rašić Bakarić, I., Tkalec, M., \& Vizek, M. (2016). Constructing a composite coincident indicator for a post-transition country. Economic Research-Ekonomska Istraživanja, 29(1), 434445. https://doi.org/10.1080/1331677x.2016.1174388.

52. Roszko-Wójtowicz E., \& Białek J. (2016). A multivariate approach in measuring innovation performance. Proceedings of Rijeka Faculty of Economics: Journal of Economics and Business, 34 (2), 443-479.

53. Sachpazidu-Wójcicka, K. (2017). Innovation as a determinant of the competitiveness of Polish enterprises. Oeconomia Copernicana, 8(2): 287-299. https://doi.org/https://doi. org/10.24136/oc.v8i2.18.

54. Saltelli, A. (2006). Composite Indicators between Analysis and Advocacy. Social indicators research, 81(1), 65-77. https://doi.org/10.1007/s11205-006-0024-9.

55. Schilcht, E. (2005). Estimating the Smoothing Parameter in the So-called Hodrick-Prescott filter. Journal of the Japanese Statistical Society, 35(1), 99-119. https://doi.org/10.14490/jiss.35.99.

56. Simionescu, M. (2016). The relation between economic growth and foreign direct investment during the economic crisis in the European Union. Proceedings of Rijeka Faculty of Economics: Journal of Economics and Business, 34(1), 187-213.

57. Simionescu M. (2016b). Competitiveness and Economic Growth in Romanian Regions. Journal of Competitiveness, 5(4), 46-60. https://doi.org/10.7441/joc.2016.04.03.

58. Simionescu, M., Gavurova, B., \& Smrčka, L. (2017a). Combined forecasts to improve Survey of Profession Forecasters predictions for quarterly inflation in the U.S.A. Economic Research-Ekonomska Istraživanja, 30(1), 789-805. http://dx.doi.org/10.1080/ 1331677X.2017.1314826.

59. Simionescu, M., Lazányi, K., Sopková, G., Dobeš, K., \& Balcerzak, A. P. (2017b). Determinants of Economic Growth in V4 Countries and Romania. Journal of Competitiveness, 9(1), 103-116. https://doi.org/10.7441/joc.2017.01.07.

60. Šegota, A., Tomljanović, M., \& Huđek, I. (2017). Contemporary approaches to measuring competitiveness - the case of EU member states. Proceedings of Rijeka Faculty of Economics: Journal of Economics and Business, 35 (1), 123-150.

61. Tendera-Właszczuk, \& H., Szymański, M. (2015). Implementation of the Welfare State in the Visegrád Countries. Economics and Sociology, 8(2): 126-142.

62. Travkina, I. 2015. Export and GDP Growth in Lithuania: Short-run or Middle-run Causality? Entrepreneurship and Sustainability Issues 3(1), 74-84. https://doi.org/10.9770/ jesi.2015.2.4(7).

63. Trimbur, T. M. (2006). Detrending economic time series: a Bayesian generalization of the Hodrick-Prescott filter. Journal of Forecasting, 25(4), 247-273. https://doi.org/10.14254/2071789x.2015/8-2/10.

64. Vincúr, P. et al. (1997). Hospodárska politika. Trnava: KON-PRESS.

65. Wirtschaftswoche (2017). Serie Frühindikatoren (VII). Earlybird-Indikator: Früher Vogel. Retrieved December 11, 2016, from http://www.wiwo.de/politik/konjunktur/seriefruehindikatoren-vii-earlybird-indikator-frueher-vogel/10306798.html. 
66. ZEW (2017). Finanzmarktreport. Einschätzungen und Erwartungen zu internationalen Finanzmarktdaten. Retrieved December 25, 2016, from http://www.zew.de/fileadmin/ FTP/frep/022017.pdf.

67. ZEW Konjunkturreport (2001). Gesamtwirtschaftliche Forschulnsergebnisse.

Prognosequalität der ZEW-Konjunkturerwartungen im Vergleich. Retrieved December 26, 2016, from ftp://ftp.zew.de/pub/zew-docs/div/Prognose_Konjunkturrep.pdf.

68. Zimková, E., \& Barochovský, J. (2007). Odhad potenciálního produktu a produkčnej medzery v slovenských podmienkach. Politická ekonomie, 11(4), 473-489. https://doi. org/10.18267/j.polek.609.

\section{Contact information}

Ing. Tkacova Andrea, PhD.

Technical University of Kosice

Faculty of Economics

Department of Finance

E-mail:andrea.tkacova@tuke.sk

doc. Ing. Gavurova Beata, PhD.

Technical University of Košice

Faculty of Economics, Department Banking and Investment

E-mail:beata.gavurova@tuke.sk

ORCID: 0000-0002-0606-879X

Ing. Bebun Marcel, PhD.

Technical University of Kosice

Institute of Earth Resources

E-mail:marcel.behun@tuke.sk 